\title{
Pengaruh Struktur Modal Terhadap Harga Saham Dengan Ukuran Perusahaan Sebagai Variabel Moderating Pada Perusahaan Property Dan Real Estate Yang Terdaftar Di Bursa Efek Indonesia
}

\author{
Achmad Faluthy \\ Magister Ilmu Manajemen, Universitas Sumatera Utara \\ Achmad.faluthy@gmail.com
}

\begin{abstract}
Abstrak
Harga saham adalah harga yang terjadi di pasar bursa pada saat tertentu yang ditentukan oleh pelaku pasar dan ditentukan oleh permintaan dan penawaran yang bersangkutan di pasar modal. Harga saham merupakan salah satu indikator keberhasilan perusahaan karena harga saham yang tinggi akan memberikan keuntungan yaitu capital gain dan prospek pertumbuhan perusahaan juga dapat terlihat dari pergerakan harga saham sehingga investor secara umum akan lebih tertarik untuk menanamkan modalnya pada perusahaan yang memberikannya keuntungan. Beberapa faktor yang mempengaruhi harga saham yaitu struktur modal dan ukuran perusahaan. Tujuan penelitian untuk mengetahui apakah struktur modal berpengaruh terhadap harga saham dengan ukuran perusahaan sebagai variabel moderating pada Perusahaan Property dan Real Estate yang terdaftar di Bursa Efek Indonesia. Sampel di dalam penelitian ini dengan menggunakan puposive sampling dengan total sampel sebanyak 10 Perusahaan Property Dan Real Estate yang terdaftar di Bursa Efek Indonesia dan data dari tahun 2014 - 2017. Teknik analisis data dengan menggunakan uji t, uji F, uji F2. Hasil penelitian ini menunjukkan bahwa struktur modal secara parsial berpengaruh signifikan terhadap harga saham pada Perusahaan Property dan Real Estate yang terdaftar di Bursa Efek Indonesia. Ukuran perusahaan mampu memoderasi struktur modal terhadap harga saham pada Perusahaan Property dan Real Estate yang terdaftar di Bursa Efek Indonesia. Ukuran perusahaan merupakan variabel moderasi dalam pengaruh struktur modal terhadap harga saham. Ukuran perusahaan akan direaksi secara positif oleh pasar karena dianggap prospek pertumbuhan yang baik di masa depan. Informasi akan laba akan direaksi semakin positif oleh pasar jika aktiva perusahaan juga tumbuh. Hal ini menunjukkan perusahaan melakukan reinvestasi yang memberikan prospek keuntungan
\end{abstract}


bagi perusahaan di masa depan, sehingga ukuran perusahaan memperkuat hubungan antara informasi akan struktur modal dan harga saham perusahaan.

Kata Kunci : Struktur Modal, Ukuran Perusahaan dan Harga Saham

\section{PENDAHULUAN}

Pasar modal memiliki peranan penting dalam perkembangan perekonomian Indonesia karena pasar modal menjalankan dua fungsi, yaitu fungsi ekonomi dan fungsi keuangan. Menurut Riyanto (2013), "dalam menjalankan fungsi ekonomi dengan cara mengalokasikan dana secara efisien dari pihak yang memiliki kelebihan dana sebagai pemilik modal (investor) kepada perusahaan yang terdaftar di pasar modal (emiten). Sedangkan fungsi keuangan dari pasar modal ditunjukkan oleh kemungkinan dan kesempatan mendapatkan imbalan (return) bagi pemilik dana atau investor sesuai dengan karakter investasi yang dipilih. Harga saham merupakan cerminan dari kegiatan pasar modal secara umum. Pasar modal sendiri selain sebagai sarana penyedia dana bagi perusahaan yang membutuhkan tambahan modal, juga berfungsi sebagai tempat yang mempertemukan antara investor sebagai pihak yang mengalami kelebihan dana dengan para perusahaan yang mengalami kekurangan dana. Dari sudut pandang investor, pasar modal merupakan sarana investasi bagi pihak yang mempunyai kelebihan dana baik jangka pendek maupun jangka menengah. Dari sudut pandang perusahaan, pasar modal adalah salah satu alternatif untuk menambah dana bagi perusahaan. Sedangkan bagi masyarakat, kehadiran pasar modal merupakan tambahan alternatif investasi yang selama ini dirasakan sangat terbatas di Indonesia. Investor akan menanamkan investasinya pada perusahaan yang dianggap dapat memberikan keuntungan. Perusahaan yang terdaftar di Bursa Efek Indonesia akan selalu dinilai perkembangannya oleh investor dan calon investor. Disini para investor dan calon investor dapat menilai apakah perusahaan tersebut memiliki prospek yang baik dimasa depan atau tidak.

Menurut Riyanto (2013), salah satu indikator utama yang mencerminkan kinerja pasar modal apakah sedang mengalami peningkatan (bullish) ataukah sedang mengalami penurunan (bearish) yaitu indeks harga saham gabungan (IHSG). Berikut ini tabel perkembangan harga saham pada Perusahaan Property Dan Real Estate yang terdaftar di Bursa Efek Indonesia. Menurut Handayani (2011), struktur modal adalah Perimbangan antara hutang dengan modal yang dimiliki perusahaan. Investor tidak hanya melihat kemampuan perusahaan untuk memperoleh laba, tetapi juga banyaknya penggunaan hutang oleh perusahaan dalam menjalankan aktivitasnya. Struktur modal adalah mengukur seberapa besar perusahaan dibiayai dengan utang. Proksi rasio hutang yang akan digunakan dalam penelitian ini adalah Debt to Equity Ratio (DER) yaitu rasio yang digunakan untuk perbandingan hutang dan ekuitas dalam pendanaan perusahaan dan menunjukkan kemampuan modal sendiri perusahaan untuk memenuhi seluruh kewajibannya. Menggunakan utang dalam jumlah besar akan meningkatkan risiko yang ditanggung pemegang saham dan cenderung akan menurunkan harga saham". Berikut ini tabel perkembangan DER pada Perusahaan Property Dan Real Estate yang terdaftar di Bursa Efek Indonesia.

Jurnal Insitusi Politeknik Ganesha Medan 
Menurut Riyanto (2013), ukuran perusahaan adalah Besar kecilnya perusahaan dilihat dari besarnya nilai ekuitas, nilai penjualan atau nilai total aset. Perusahaan besar akan lebih mendapat perhatian dari investor karena dianggap kondisi keuangannya lebih stabil. Kestabilan itulah yang menjadi daya tarik investor yang pada dasarnya ingin meminimalkan sekecil mungkin terhadap risiko kerugian. Investor memiliki ekspektasi yang besar terhadap perusahaan besar. Diharapkan perusahaan besar dapat memberikan dividen yang besar pula kepada para pemegang sahamnya. Peningkatan permintaan saham akan diikuti oleh naiknya harga saham di pasar modal dan hal tersebut mencerminkan naiknya nilai perusahaan. Berikut ini tabel perkembangan ukuran perusahaan pada Perusahaan Property Dan Real Estate yang terdaftar di Bursa Efek Indonesia.

Fenomena yang terjadi dimana penurunan rata-rata harga saham pada tahun 2016 sebesar Rp.1.493 dan tahun 2017 sebesar Rp.1.426, dari tahun sebelumnya, maka hal ini akan berdampak pada menurunnnya tingkat kemakmuran pemegang saham. Beberapa faktor yang mempengaruhi harga saham yaitu struktur modal dengan ukuran perusahaan sebagai variabel moderating. Menurunnya rata-rata debt to equity ratio pada tahun 2015 sebesar 98,83\% dan tahun 2016 sebesar $255,46 \%$, dari tahun sebelumnya, hal ini berdampak pada pendanaan dengan menggunakan utang yang terlalu tinggi akan meningkatkan risiko keuangan perusahaan dan pada akhirnya dapat mengakibatkan financial distress sehingga nilai perusahaan akan menurun. Rata-rata ukuran perusahaan menurun pada tahun 2016 sebesar Rp.14.066.790 juta, dari tahun sebelumnya, hal ini berdampak pada kecilnya dana yang akan dibutuhkan untuk kegiatan operasional perusahaan.

Adanya research gap (perbedaan hasil penelitian terdahulu), dimana hasil penelitian Pratiwi (2018), menunjukkan bahwa stuktur modal tidak berpengaruh signifikan terhadap harga saham, sedangkan Wehantouw (2017), menunjukkan bahwa stuktur modal berpengaruh signifikan terhadap harga saham. Hasil penelitian Wehantouw (2017), menunjukkan bahwa ukuran perusahaan berpengaruh signifikan terhadap harga saham, sedangkan Gunarso (2014), menunjukkan bahwa ukuran perusahaan tidak berpengaruh signifikan terhadap harga saham. Hasil ini menunjukkan adanya perbedaan hasil penelitian terdahulu.

Ukuran perusahaan merupakan variabel moderasi dalam pengaruh struktur modal terhadap harga saham. Ukuran perusahaan akan direaksi secara positif oleh pasar karena dianggap prospek pertumbuhan yang baik di masa depan. Informasi akan laba akan direaksi semakin positif oleh pasar jika aktiva perusahaan juga tumbuh. Hal ini menunjukkan perusahaan melakukan reinvestasi yang memberikan prospek keuntungan bagi perusahaan di masa depan, sehingga ukuran perusahaan memperkuat hubungan antara informasi akan struktur modal dan harga saham perusahaan. Perusahaan yang memiliki ukuran perusahaan tinggi, harga sahamnya juga tinggi, dan perusahaan yang memiliki ukuran perusahaan rendah, harga sahamnya juga rendah. Dari kondisi tersebut tampak bahwa semakin tingginya ukuran perusahaan maka akan membuat investor tertarik dan menjadikannya sebagai indikator dalam berinvestasi. Jadi perusahaan akan lebih mudah untuk mendapatkan sumber pendanaan atau struktur modal jika ukuran perusahaan tersebut semakin besar. Struktur modal tersebut dapat dimanfaatkan oleh pihak manajemen untuk tujuan meningkatkan harga saham.

Jurnal Insitusi Politeknik Ganesha Medan 


\section{Struktur Modal}

\section{LANDASAN TEORI}

Perimbangan antara hutang dengan modal yang dimiliki perusahaan. (Handayani, 2011).

\section{Ukuran Perusahaan}

Besar kecilnya perusahaan dilihat dari besarnya nilai ekuitas, nilai penjualan atau nilai total aset. (Riyanto, 2013).

\section{Harga Saham}

Harga yang terjadi di pasar bursa pada saat tertentu yang ditentukan oleh pelaku pasar dan ditentukan oleh permintaan dan penawaran yang bersangkutan di pasar modal (Jogiyanto, 2016:96).

\section{METODE PENELITIAN}

Pendekatan penelitian ini adalah penelitian asosiatif. Penelitian asosiatif adalah yaitu penelitian yang menghubungkan dua variabel atau lebih. Metode penelitian uji moderating adalah variabel yang memperkuat atau memperlemah hubungan antara satu variabel dengan variabel lain. Adapun populasi dalam penelitian ini sebanyak 10 perusahaan Property \& Real Estate Yang Terdaftar di BEI pada tahun 2014 hingga tahun 2017. Sedangkan teknik pengumpulan data pada penelitian ini diperoleh dengan teknik observasi, wawancara dan kepustakaan. Pengolahan data menggunakan perangkat lunak SPSS 16.0For Windows. Analisis statisitk inferensial dalam penelitian ini meliputi: uji asumsi klasik, regresi analisis jalur, uji hipotesis.

\section{HASIL DAN PEMBAHASAN \\ Pengaruh Struktur Modal Terhadap Harga Saham}

Hasil menunjukkan bahwa struktur modal berpengaruh tidak signifikan terhadap harga saham. Nilai struktur modal berpengaruh signifikan negatif terhadap harga saham, artinya semakin tinggi nilai struktur modal maka akan semakin turun pula harga saham. Besarnya koefisien regresi struktur modal adalah $-0,034$, artinya jika nilai struktur modal meningkat Rp. $1 \%$ maka akan diikuti penurunan harga saham Rp 0.034. Sebaliknya jika terjadi penurunan nilai DER Rp.1\% maka akan diikuti peningkatan harga saham sebesar Rp0.034. Hasil penelitian sesuai dengan Pratiwi (2018), menunjukkan bahwa stuktur modal tidak berpengaruh signifikan terhadap harga saham, sedangkan hasil ini bertentangan dengan penelitian Wehantouw (2017), menunjukkan bahwa stuktur modal berpengaruh signifikan terhadap harga saham.

Berdasarkan teori Handyani (2011), struktur modal yaitu perimbangan antara hutang dengan modal yang dimiliki perusahaan, dimana struktur modal diukur dengan menggunakan Debt to Equity (DER). Debt to Equity (DER) merupakan rasio yang membandingkan jumlah hutang terhadap ekuitas perusahaan. Rasio ini digunakan para analis dan investor untuk melihat seberapa besar hutang perusahaan jika dibandingkan dengan ekuitas yang dimilik perusahaan atau para pemegang saham. 
Struktur modal mengungkapkan bagaimana penggunaan pendanaan perusahaan dari struktur modal yang dimiliki oleh perusahaan yang berasal dari utang jangka panjang dan modal yang berasal dari ekuitas. Struktur modal berpengaruh negatif terhadap harga saham menunjukkan bahwa investor memperhatikan berapa besar modal yang dibiayai oleh mereka kepada perusahaan untuk menghasilkan laba bersih untuk mereka. Semakin besar struktur modal menandakan struktur permodalan usaha lebih banyak memanfaatkan dana yang disediakan oleh kreditur untuk membayar hutang. Dapat disimpulkan bahwa struktur modal pada tingkat tertentu memiliki pengaruh negatif dan tidak signifikan terhadap harga saham perusahaan. Tidak berpengaruhnya struktur modal terhadap harga saham dapat dilihat dari meningkatnya struktur modal tidak ikutin dengan peningkatan harga saham.

\section{Pengaruh Struktur Modal Terhadap Harga Saham Dengan Ukuran Perusahaan Sebagai Variabel Moderating}

Hasil menunjukkan bahwa pengujian moderating dengan nilai residual yang diabsolutkan, diketahui bahwa nilai regresi yang negatif yaitu $-3,548$ dan tidak signifikan $0,013<0,05$. Hasil tersebut dapat disimpulkan bahwa ukuran perusahaan sebagai variabel moderating, dimana dengan meningkatnya struktur modal dapat memperlemah hubungan antara struktur modal terhadap harga saham. Hal ini menunjukkan bahwa peningkatan ukuran perusahaan sebesar Rp.1 juta makan akan mempengaruhi peningkatan struktur modal, dimana perusahaan akan membutukan dana eksternal yaitu hutang dalam peningkatan aset atau ukuran perusahaan, sehingga hal ini akan berpengaruh signifikan pada penurunan harga saham sebesar Rp.3,548. Hasil penelitian sesuai dengan penelitian Pratiwi (2019), menunjukkan bahwa ukuran perusahaan memoderasi hubungan antara struktur modal terhadap harga saham, sedangkan hasil ini bertentangan dengan penelitian Gunarso (2014), menunjukkan bahwa ukuran perusahaan tidak memoderasi hubungan antara struktur modal terhadap harga saham.

Ukuran perusahaan merupakan variabel moderasi dalam pengaruh struktur modal terhadap harga saham. Ukuran perusahaan akan direaksi secara negatif oleh pasar karena dianggap prospek pertumbuhan kurang baik di masa depan. Informasi akan laba akan direaksi semakin negatif oleh pasar jika aktiva perusahaan juga tumbuh. Hal ini menunjukkan perusahaan melakukan reinvestasi yang tidak memberikan prospek keuntungan bagi perusahaan di masa depan, sehingga ukuran perusahaan memperlemah hubungan antara informasi akan struktur modal dan harga saham perusahaan. Perusahaan yang memiliki ukuran perusahaan tinggi, maka harga sahamnya akan menurun. Dari kondisi tersebut tampak bahwa semakin tingginya ukuran perusahaan maka akan membuat investor tertarik dan menjadikannya sebagai indikator dalam berinvestasi. Jadi perusahaan akan lebih mudah untuk mendapatkan sumber pendanaan atau struktur modal jika ukuran perusahaan tersebut semakin besar, sehingga perusahaan hanya focus dalam membayar hutang untuk peningkatan ukuran perusahaan dan berdampak negatif pada harga saham.

\section{KESIMPULAN}

Berdasarkan hasil penelitian dan pembahasan pada penelitian ini, maka dapat disimpulkan bahwa struktur modal secara parsial berpengaruh tidak signifikan 
terhadap harga saham pada Perusahaan Property dan Real Estate yang terdaftar di Bursa Efek Indonesia. Sedangkan ukuran perusahaan mampu memoderasi struktur modal terhadap harga saham pada Perusahaan Property dan Real Estate yang terdaftar di Bursa Efek Indonesia.

\section{REFERENSI}

Ariyanti, Sari. (2016). Pengaruh Profitabilitas Dan Struktur Modal Terhadap Harga Saham (Studi pada Perusahaan Konstruksi dan Bangunan yang Terdaftar di Bursa Efek Indonesia Periode 2011-2014).

Asril. (2011). Pasar Modal (Penawaran Umum dan Permasalahannya), Citra Aditya Bakti, Bandung

Astuti, Dewi. (2011). Manajemen Keuangan Perusahaan, Ghalia Indonesia, Jakarta.

Brigham, Eugene dan Joel F. Houston, (2011), Manajemen Keuangan, Edisi 8, Buku Kedua, Alih Bahasa Dodo Suharto dan Herman Wibowo, Erlangga, Jakarta.

Erlina, (2013). Metodologi Penelitian, USU Press, Medan.

Ghozali, Imam, (2015). Analisis Multivariat dengan Program SPSS, Edisi Ketiga, Badan Penerbit Universitas Diponegoro, Semarang.

Gunarso, Pujo. (2014). Laba Akuntansi, Struktur Modal, Dan Ukuran Perusahaan Terhadap Harga Saham Di Bursa Efek Indonesia.

Handayani, Bestasari Dwi. (2011)." Pengaruh Struktur Modal terhadap Nilai Perusahaan pada Perusahaan sedang Bertumbuh yang Berbeda (Theory Agency)", UNS, jurnal Bisnis dan Ekonomi, volume 6, edisi 1

Harahap, Sofyan Syafri, (2013). Analisis Kritis Atas Laporan Keuangan, PT Rajagrafindo Persada, Jakarta.

Harmono. (2018). Manajemen Keuangan. Berbasis Balanced Scorecard Pendekatan Teori, Kasus, dan Riset Penelitian.

Mahendra, Alfredo. (2011)." Pengaruh Kinerja Keuangan terhadap Nilai Perusahaan (Kebijakan Deviden sebagai Variabel Moderating) pada PerusahaanManufaktur di Bursa Efek Indonesia.", Universitas Udayana, Tesis.

Musfitria, Anessa. (2016). Pengaruh Dividen Dan Struktur Modal Terhadap Perkiraan Harga Saham (Studi pada Perusahaan yang tercatat di Bursa Efek Indonesia Periode 2006-2011).

Pratiwi, Kurniawati. (2018). Pengaruh Struktur Modal Dan Profitabilitas Terhadap Harga Saham (Studi pada Perusahaan Makanan dan Minuman yang Terdaftar Di Bursa Efek Indonesia Periode 2013 - 2015).

Pratiwi, Monica Weni. (2019). Analisis Pengaruh Stuktur Modal Terhadap Harga Saham Dengan Ukuran Perusahaan Sebagai Variabel Moderasi. Universitas Bakrie. Journal of Entrepreneurship, Management, and Industry (JEMI). Vol. 2, No. 1, (2019), pp. 61-68.

Riyanto, Bambang, (2013), Dasar - Dasar Pembelanjaan Perusahaan, BPFE, Yogyakarta.

Widjayanto Nugroho. 2001. Pemeriksaan Operasional Perusahaan. Jakarta: Lembaga Penerbitan Fakultas Ekonomi Indonesia. 